\title{
Effect of graded levels of dietary crude protein on nutrient utilization and enteric methane emissions in growing Murrah buffalo calves
}

\author{
Sonam Dixit ${ }^{1}$, Anchal Keshri ${ }^{2}$, Vinay VV ${ }^{3}$ and SS Kundu ${ }^{4}$
}

Received: 27 March 2021 / Accepted: 16 September 2021/Published online: 21 December 2021

(c) Indian Dairy Association (India) 2021

\begin{abstract}
The present study was done to investigate the effect of graded levels of dietary crude protein on enteric methane $\left(\mathrm{CH}_{4}\right)$ production from Murrah buffalo calves. Fifteen Murrah buffalo male calves were divided into 5 groups $(\mathrm{Av}$. $\mathrm{BW}=153.05)$ and were fed total mixed rations containing wheat straw, maize fodder and concentrate mixture in different proportions so that the dietary crude protein level was $5,7.5,10,12.5$ and $15 \%$ in groups $\mathrm{T}_{1}, \mathrm{~T}_{2}, \mathrm{~T}_{3}, \mathrm{~T}_{4}$ and $\mathrm{T}_{5}$ respectively. The trial lasted for 30 days. Dry matter intake increased from 2.49 to $4.40 \mathrm{~kg} / \mathrm{d}$. Dry matter digestibility increased $(\mathrm{P}<0.05)$ from 48.64 to $61.97 \% . \mathrm{CH}_{4}$ emissions decreased $(\mathrm{P}<0.05)$ from 34.48 to $12.73 \mathrm{~g} / \mathrm{kg}$ DMI with increasing protein level in the ration. Hence, $\mathrm{CH}_{4}$ emissions were lower (12.73-12.83 g/Kg DMI) in animals fed rations containing 12.5 to $15 \% \mathrm{CP}$.
\end{abstract}

Keywords: Buffalo calves, Enteric $\mathrm{CH}_{4}$ emissions, Nutrient utilization

Concern of world environmental authorities towards increasing level of green house gases (GHGs) in the atmosphere is due to their global warming impacts. $\mathrm{CH}_{4}$ is the second most important greenhouse gas after carbon dioxide due to its 25 times higher

\footnotetext{
${ }^{1}$ Government Veterinary Hospital, Distt- Auraiya- 206122, Uttar Pradesh, India

Email: sonamdxt378@gmail.com

${ }^{2}$ College of Veterinary Science and Animal Husbandry, Mhow-453446, Madhya Pradesh, India.

Email: anchalkeshri05@gmail.com

${ }^{3}$ Animal Nutrition Division, ICAR-NDRI, Karnal-132001, Haryana, India. Email: vinayvv694@gmail.com

${ }^{4} 1-94$, Sipra Sun City, Indirapuram, Ghaziabad-201014, Uttar Pradesh, India.

Email:sskundu.kln@gmail.com

Sonam Dixit $(\square)$

Government Veterinary Hospital, Distt- Auraiya- 206122, Uttar Pradesh, India

Email: sonamdxt378@gmail.com
}

global warming potential (Prathap et al. 2021). Ruminant livestock constitute the most important source of anthropogenic emissions of $\mathrm{CH}_{4}$ (Broucek, 2014) and enteric fermentation and manure management (along with nitrous oxide) are the two responsible forms (Nampoothiri et al. 2018).

Due to prevailing feeding practices in the country where poor quality roughages forms major constituents of animal diet, production of acetate is more which contributes to higher $\mathrm{CH}_{4}$ production and poor productivity of animals (Garg et al. 2012). Imbalanced feeding resulted in low milk production, poor growth and reproduction, shorter lactation length, longer calving intervals and excessive amounts of pollutants released into the environment (Gupta et al. 2019). Though biotechnological and management methods are quite tedious, manipulating methanogenic causes through feed interventions are more researched and adoptive ways (Prathap et al. 2021). Supplementation of concentrate or increasing the dietary crude protein in the ration is being practiced over the years to reduce $\mathrm{CH}_{4}$ emissions (Muñoz et al. 2015). Thus, the present study was aimed to investigate the effect of using different crude protein in the ration on nutrient utilization and $\mathrm{CH}_{4}$ production in Murrah buffalo calves.

Fifteen male Murrah buffalo calves (153.05 kg BW, 6-8 mon.) at Livestock Research Centre (LRC) of ICAR-National Dairy Research Institute (NDRI), Karnal, India, were distributed randomly in five groups of three each based on body weight and age. The animals were fed on graded levels of protein in the ration i.e. total mixed rations containing wheat straw, maize green and concentrate mixture in different proportions so that the dietary CP level was 5,7.5, 10, 12.5 and $15 \%$ of $\mathrm{DMI}$ in groups $\mathrm{T}_{1}$ (R:C=100:0), $T_{2}(R: C=80: 20) T_{3}(R: C=70: 30), T_{4}(R: C=65: 35)$ and $T_{5}$ ( $\mathrm{R}: \mathrm{C}=55: 45)$, respectively. The feeding trial lasted for 30 days, followed by a 7 day metabolic trial. Dry matter intake was recorded daily for each animal. The samples of feed, residue, feces and urine were analyzed for proximate principles (AOAC 2005) and NDF (Van Soest et al. 1991). Non-fibrous carbohydrates (NFC), total digestible nutrients (TDN), digestible energy (DE) and metabolizable energy (ME) values were calculated from feed composition using equations (NRC, 2001). 
Enteric $\mathrm{CH}_{4}$ emission was measured for a total of 5 days (i.e. minimum of 5 samples per animal) using $\mathrm{SF}_{6}$ tracer technique (Johnson et al. 1994). Collected samples (gases eructed from the mouth and nostrils) were analyzed for $\mathrm{CH}_{4}$ and $\mathrm{SF}_{6}$ gas using chromatograph (Nucon-5700, New Delhi) fitted with flame ionization detector (FID at $100^{\circ} \mathrm{C}$ ) and electron capture detector $\left(\mathrm{ECD}\right.$ at $\left.250^{\circ} \mathrm{C}\right)$, respectively. Nitrogen was used as the carrier gas at a pressure of $1 \mathrm{~kg} / \mathrm{cm}^{2}$. The $\mathrm{CH}_{4}$ emission rate was calculated as:

1000

$$
\mathrm{CH}_{4}(\mathrm{~g} / \text { day })=\left(\mathrm{S}_{\mathrm{CH} 4}-\mathrm{B}_{\mathrm{CH} 4}\right) /\left(\mathrm{S}_{\mathrm{SF} 6}-\mathrm{B}_{\mathrm{SF} 6}\right) \times\left(\mathrm{M}_{\mathrm{CH} 4} / \mathrm{M}_{\mathrm{SF} 6}\right) \times \mathrm{Q}_{\mathrm{SF} 6} \mathrm{X}
$$

Where, $\mathrm{S}_{\mathrm{CH} 4}$ and $\mathrm{B}_{\mathrm{CH} 4}$ are $\mathrm{CH}_{4}$ concentrations in sample and background's canisters; $\mathrm{S}_{\mathrm{SF} 6}$ and $\mathrm{B}_{\mathrm{SF} 6}$ represents the concentrations of $\mathrm{SF}_{6}$ in sample and background's canisters (ppt), respectively and $\mathrm{Q}_{\mathrm{SF} 6}$ represents the release rate of $\mathrm{SF}_{6}(\mathrm{mg} / \mathrm{d})$.

Statistical analysis was done using completely randomized design, one-way classification as per the procedure given by Snedecor and Cochran (1994). Significant differences among different treatments were identified using Duncan's Multiple Range Test and a $\mathrm{p}<0.05$ was considered to be statistically significant._All the statistical analyses were done using SPSS version 16_(2010).

Concentrate mixture, maize green and wheat straw were fed to the five groups in the form of TMR in such a fashion so as to provide a total dietary CP level of $5,7.5,10,12.5$ and $15 \%$ in groups $\mathrm{T}_{1}, \mathrm{~T}_{2}, \mathrm{~T}_{3}, \mathrm{~T}_{4}$ and $\mathrm{T}_{5}$, respectively. Chemical composition and the energy content of the feeds have been presented in Table 1 and were in agreement with the earlier reports (Dixit et al. 2015; Budhani et al. 2016).

Nutrient intake and digestibility figures have been shown in Table 2. The DM intake was the lowest $(\mathrm{P}<0.05)$ in group $\mathrm{T}_{1}(2.49 \mathrm{~kg} / \mathrm{d})$ and the differences among other groups were not significant, however, $\mathrm{CP}$ intake increased $(\mathrm{P}<0.05)$ with increasing levels of protein in the diet. Feed intake is partially dictated by physical capacity of the rumen, especially, in higher forage diets which might have reduced DMI (Nampoothiri et al. 2018).

Table 1 Chemical composition of experimental feeds (\% DM basis)

\begin{tabular}{llll}
\hline Attribute & Concentrate mixture & Maize fodder & Wheat straw \\
\hline Chemical composition (\%) & & & \\
DM & $91.36 \pm 0.51$ & $24.14 \pm 0.78$ & $93.05 \pm 0.04$ \\
OM & $90.69 \pm 0.41$ & $88.67 \pm 0.12$ & $86.41 \pm 0.15$ \\
CP & $20.86 \pm 0.04$ & $8.14 \pm 0.54$ & $3.02 \pm 0.47$ \\
EE & $5.02 \pm 0.10$ & $1.45 \pm 0.80$ & $1.02 \pm 0.15$ \\
TA & $9.31 \pm 0.63$ & $11.33 \pm 0.05$ & $12.59 \pm 0.85$ \\
NFC & $37.53 \pm 0.18$ & $21.44 \pm 0.10$ & $10.72 \pm 0.01$ \\
NDF & $25.83 \pm 0.16$ & $56.63 \pm 0.24$ & $70.66 \pm 0.81$ \\
ADF & $13.67 \pm 0.77$ & $28.41 \pm 0.35$ & $42.61 \pm 0.84$ \\
Energy content & & & $41.70 \pm 0.88$ \\
TDN (\%) & $74.59 \pm 1.96$ & $52.10 \pm 2.03$ & $7.66 \pm 0.12$ \\
DE (MJ/Kg DM) & $14.32 \pm 0.89$ & $9.69 \pm 0.54$ & $5.82 \pm 0.17$ \\
ME (MJ/Kg DM) & $12.62 \pm 0.30$ & $7.87 \pm 0.26$ & \\
\hline
\end{tabular}

$\mathrm{DM}=$ Dry Matter; TA=Total Ash; $\mathrm{OM}=$ Organic Matter; $\mathrm{CP}=$ Crude Protein; $\mathrm{EE}=$ Ether Extract; NDF=Neutral Detergent Fiber; $\mathrm{ADF}=$ Acid Detergent Fiber; NFC=Non-Fibrous Carbohydrates; TDN=Total Digestible Nutrients; DE=Digestible Energy; $\mathrm{ME}=$ Metabolizable Energy

Table 2 Nutrient intake and digestibility in buffaloes given different levels of protein in diet

\begin{tabular}{llllll}
\hline Particular & $\mathrm{T}_{1}$ & $\mathrm{~T}_{2}$ & $\mathrm{~T}_{3}$ & $\mathrm{~T}_{4}$ & $\mathrm{~T}_{5}$ \\
\hline BW $(\mathrm{kg})$ & $151.22 \pm 2.67$ & $152.23 \pm 4.01$ & $156.21 \pm 3.78$ & $155.51 \pm 4.08$ & $150.08 \pm 3.62$ \\
Nutrient intake & & & & & \\
DMI $(\mathrm{kg})$ & $2.49^{\mathrm{a}} \pm 0.28$ & $3.38^{\mathrm{ab}} \pm 0.29$ & $4.04^{\mathrm{b}} \pm 0.24$ & $4.26^{\mathrm{b}} \pm 0.29$ & $4.40^{\mathrm{b}} \pm 0.59$ \\
CP intake (g/day) & $100.69^{\mathrm{a}} \pm 3.54$ & $257.28^{\mathrm{b}} \pm 36.85$ & $400.28^{\mathrm{c}} \pm 51.40$ & $519.89^{\mathrm{d}} \pm 64.44$ & $587.49^{\mathrm{d}} \pm 76.14$ \\
Digestibility of nutrients $(\%)$ & & & & \\
DM & $48.64^{\mathrm{a}} \pm 0.77$ & $50.45^{\mathrm{a}} \pm 1.36$ & $55.07^{\mathrm{ab}} \pm 0.56$ & $60.67^{\mathrm{c}} \pm 1.57$ & $61.97^{\mathrm{c}} \pm 0.91$ \\
OM & $50.90^{\mathrm{a}} \pm 0.12$ & $53.17^{\mathrm{b}} \pm 0.94$ & $57.01^{\mathrm{b}} \pm 1.78$ & $63.56^{\mathrm{c}} \pm 0.49$ & $65.61^{\mathrm{c}} \pm 0.17$ \\
CP & $45.45^{\mathrm{a}} \pm 3.01$ & $70.32^{\mathrm{b}} \pm 1.24$ & $75.47^{\mathrm{b}} \pm 2.67$ & $80.18^{\mathrm{c}} \pm 1.45$ & $81.94^{\mathrm{c}} \pm 1.08$ \\
NDF & $50.23 \pm 2.98$ & $53.74 \pm 2.69$ & $53.19 \pm 4.78$ & $56.77^{ \pm} \pm 3.29$ & $50.62 \pm 3.94$ \\
ADF & $43.69 \pm 1.99$ & $46.95 \pm 5.01$ & $43.78 \pm 1.33$ & $45.45 \pm 1.45$ & $43.86 \pm 3.28$ \\
\hline
\end{tabular}

${ }^{a b c}$ Means bearing different superscripts in the same row differ significantly $(\mathrm{P}<0.05)$ 
Table 3 Enteric $\mathrm{CH}_{4}$ emissions in calves as affected by crude protein content in the rations

\begin{tabular}{llllll}
\hline Particular & $\mathrm{T}_{1}$ & $\mathrm{~T}_{2}$ & $\mathrm{~T}_{3}$ & $\mathrm{~T}_{4}$ & $\mathrm{~T}_{5}$ \\
\hline $\mathrm{CH}_{4}(\mathrm{~g} / \mathrm{d})$ & $84.07^{\mathrm{a}} \pm 1.95$ & $66.93^{\mathrm{b}} \pm 1.17$ & $61.80^{\mathrm{c}} \pm 0.71$ & $54.07^{\mathrm{d}} \pm 1.23$ & $54.40^{\mathrm{d}} \pm 2.06$ \\
$\mathrm{CH}_{4}(\mathrm{~g} / \mathrm{kg} \mathrm{DMI})$ & $34.48^{\mathrm{a}} \pm 3.45$ & $20.08^{\mathrm{b}} \pm 1.52$ & $15.39^{\mathrm{bc}} \pm 0.70$ & $12.83^{\mathrm{c}} \pm 0.99$ & $12.73^{\mathrm{c}} \pm 1.34$ \\
$\mathrm{CH}_{4}$ loss & & & & & \\
\% of GE intake & $11.75^{\mathrm{a}} \pm 1.23$ & $6.66^{\mathrm{b}} \pm 0.74$ & $5.04^{\mathrm{bc}} \pm 0.44$ & $4.32^{\mathrm{c}} \pm 0.82$ & $3.95^{\mathrm{c}} \pm 0.37$ \\
\% of DE intake & $23.00^{\mathrm{a}} \pm 3.39$ & $11.58^{\mathrm{b}} \pm 1.36$ & $8.19^{\mathrm{c}} \pm 1.57$ & $6.61^{\mathrm{d}} \pm 0.47$ & $5.58^{\mathrm{d}} \pm 0.67$ \\
\% of ME intake & $29.75^{\mathrm{a}} \pm 3.97$ & $14.34^{\mathrm{b}} \pm 1.59$ & $9.92^{\mathrm{c}} \pm 1.88$ & $7.87^{\mathrm{d}} \pm 0.94$ & $6.94^{\mathrm{d}} \pm 0.36$ \\
\hline
\end{tabular}

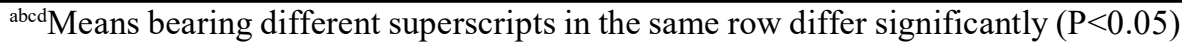

Enteric $\mathrm{CH}_{4}$ emissions data have been presented in Table 3. On an average, $\mathrm{CH}_{4}$ emission in groups $\mathrm{T}_{3}$ to $\mathrm{T}_{5}(12.73-15.39 \mathrm{~g} / \mathrm{kg}$ $\mathrm{DMI})$ found in agreement in case of growing Murrah calves i.e. 9.47-13.6 g/kg DMI (Nampoothiri et al. 2018), 12.2-13.3 g/kg DMI (Gupta et al. 2019) and 11.43-16.17 g/kg DMI (Budhani et al. 2016); however, $\mathrm{CH}_{4}$ production in groups $\mathrm{T}_{1}$ and $\mathrm{T}_{2}$ were not comparable, might be due to low crude protein feed structure than the average feeding patterns of the rations. $\mathrm{CH}_{4}$ loss represented similar loss of GE intake in the previous work (Appuhamy et al. 2016) resulting in reduced feed efficiency in the animals.

Thakur et al. (2021) found that increasing concentrate portion from $70-20 \%$ in the ration reduced the enteric $\mathrm{CH}_{4}$ emission by $34.18 \%$ in crossbred kids. However, enteric $\mathrm{CH}_{4}$ production was not affected by increasing CP content (14.1-18.1\%) in the concentrate (Hynes et al. 2016). By selecting higher feed efficient animals, $\mathrm{CH}_{4}$ production in the fermentation process of rumen can be reduced by decreasing CP content (130-175 g/ $\mathrm{kg} \mathrm{DM})$ of the ration due to less urinary nitrogen losses (Kidane et al. 2018). Similar results have been reported (Niu et al. 2016) but with a higher level of CP (18.5\%) in the diet.

Shifting the ration from concentrates to fibrous feed, higher acetate and butyrate levels, being the precursor for $\mathrm{CH}_{4}$ production in the rumen levels caused higher $\mathrm{CH}_{4}$ emissions (Dijkstra et al. 2011). Decreased $\mathrm{CH}_{4}$ production by increasing $\mathrm{CP}$ content did not affect $\mathrm{CH}_{4}$ emission in absolute terms i.e. L/ day but there was reduction in $\mathrm{CH}_{4}$ emission as a proportion of DMI, milk yield and GE intake (Sherasia and Garg 2016) as availability of grains causes formation of more propionate which does not provide $\mathrm{H}_{2}$ for methanogenesis (Niu et al. 2016). However, accounting $\mathrm{CH}_{4}$ emission per $\mathrm{kg}$ milk produced make sense only in the higher milk production animals (Muñoz et al. 2015) which negotiated the $\mathrm{CH}_{4}$ production with higher milk yield. Higher grain content of concentrate led to increase in starch level in rumen, thereby, reducing ruminal $\mathrm{pH}$ and activity of protozoa and methanogens (Uddin et al. 2020).

\section{Conclusions}

Increasing proportion of dietary $\mathrm{CP}$ in the ration increased dry matter intake, nutrient intake and nutrient digestibility along with reduction in $\mathrm{CH}_{4}$ emissions in growing Murrah buffaloes.
Therefore, $12.5-15 \% \mathrm{CP}$ in the ration of growing Murrah buffaloes may be recommended based on the results of present study.

\section{Acknowledgements}

The authors thank Director, ICAR-National Dairy Research Institute, Karnal, Haryana, India for the financial support.

\section{References}

AOAC (2005) Official Methods of Analysis, $18^{\text {th }}$ edition. Association of Official Analytical Chemists, Arlington, VA, USA

Broucek, J (2014) Production of methane emissions from ruminant husbandry: A Review. J Env Prot 5: 1482-1493

Budhani L, Mohini M, Datt C, Thakur SS (2016) Influence of paddy straw of different particle sizes in the diet on nutrientutilisation and enteric methane emissions in murrah buffalo Calves. Indian J Anim Nutr 33: 11-16

Dijkstra J, Oenema O, Bannink A (2011) Dietary strategies to reducing N excretion from cattle: implications for methane emissions. Curr Opin Environ Sustain 3:414-422

Dixit S, Kundu SS, Sontakke U, Prusty S (2015) Derivation of metabolic faecal nitrogen excretion in Murrah buffalo calves fed graded levels of protein in the diet. Indian J Anim Nutr 32: 148-153

Garg MR, Kannan A, Phondba BT, Shelke SK, Sherasia PL (2012) A Study on the Effect of Ration Balancing for improving milk production and reducing methane emission in lactating buffaloes under field conditions. Indian J Dairy Sci 65: 250-255

Gupta S, Mohini M, Malla BA, Mondal G, Pandita S (2019) Effects of monensin feeding on performance, nutrient utilization and enteric methane production in growing buffalo heifers. Trop Anim Health Prod 51:859-66

Hynes DN, Stergiadis S, Gordon A, Yan T (2016) Effects of concentrate crude protein content on nutrientdigestibility, energy utilization, and methane emissions inlactating dairy cows fed freshcutperennial grass. J Dairy Sci 99: 8858-8866

Johnson KA, Huyler MT, Westburg HH, Lamb BR, Zimmerman P (1994) Measurement of methaneemission from ruminant livestock using a SF6 technique. Environ Sci Technol 28: 113-128

Kidane A, Øverland M, Mydland LT, Prestløkken E (2018) Interaction between feed use efficiency and level of dietary crude protein on enteric methane emission and apparent nitrogen use efficiency with Norwegian Red dairy cows. J Anim Sci 96:3967-3982

Muñoz C, Hube S, Morales JM, Yan T, Ungerfeld EM (2015) Effects of concentrate supplementation on enteric methane emissions and milk production of grazing dairy cows. Livest Sci $175: 37-46$

Nampoothiri VM, Madhu M, Malla BA, Mondal G, Pandita S (2018) Growth performance, and enteric and manure greenhouse gas emissions from Murrah calves fed diets with different forage to concentrate ratios. Animal Nutr 4:215-221 
Niu M, Appuhamy JADRN, Leytem AB, Dungan RS, Kebreab E (2016) Effect of dietary crude protein and forage contents on enteric methane emissions and nitrogen excretion from dairy cows simultaneously. Anim Prod Sci 56:312-321

NRC (2001) Nutrient Requirements of Dairy Cattle. $7^{\text {th }}$ edition. National Academy Press, Washington, DC

Prathap P, Chauhan SS, Leury BJ, Cottrell JJ, Dunshea FR (2021) Towards Sustainable Livestock Production: Estimation of Methane Emissions and Dietary Interventions for Mitigation. Sustainability 13(11):6081

Sherasia PL, Garg MR (2016) Ration Balancing: A Practical Strategy for Reducing Enteric MethaneEmission and Carbon Footprint of Milk in India: A Review. Indian J AnimNutr 33(4):360- 369

Snedecor GW, Cochran WB (1994) Statistical Methods 8th edition. The Iowa State University Press, Ames, IOWA, USA

Thakur S, Moini M, Malik, TA, Howal S, Varun TK, Madavi A, Yadev RD, Mondal G, Datt C (2021) Performance of crossbred goat kids fed with diets varying in concentrate-to-forage ratio: intake, nutrient utilization, enteric methane emission and body weight changes. Biol Rhythm Res 52 :133-1341

Uddin ME, Larson RA, Wattiaux MA (2020) Effects of dairy cow breed and dietary forage on greenhouse gas emissions from manure during storage and after field application. J Cleaner Prod 270:122461

Van Soest PJ, Robertson JB, Lewis BA (1991) Methods for dietary fiber, neutral detergent fiber and non-starch polysaccharides in relation to animal nutrition. Carbohydrates: methodology, metabolism and nutritional implications in dairy cattle. J Dairy Sci 74: 3583-3597 